Elena Tealdi

\title{
Political Propheticism. John of Rupescissa's Figure of the End Times Emperor and its Evolution
}

This article examines the connection between political prophecy and apocalyptical expectations during the Middle Ages. It focuses on the figure of the emperor of the end times in John of Rupescissa's prophetical commentaries and works. In Rupescissa's thinking, the figure of this final emperor is key to his exploration of the interaction between a universal temporal power and the spiritual one. The emperor's role in Rupescissa's eschatological thinking developed as the European political balance, and particular the position of France, changed. The analysis of Rupescissa's use and evolving interpretations of various prophetical sources highlights the different roles played by the temporal power in the expected imminent events of tribulation and salvation.

\section{Political Prophecy and John of Rupescissa}

In her book Prophecy and Public Affairs in Later Medieval England, Lesley Ann Coote answers the preliminary question "What is political prophecy?" by giving an interesting definition of prophecy: "Prophecy is not a genre but a discourse", before continuing that "political prophecy was not a code but a living language". ${ }^{1}$ This definition can surely be applied to the prophecies of the Friar Minor John of Rupescissa (c. 1310-ca. 1366), which were closely connected to contemporary political developments and were adjusted accordingly throughout the author's lifetime. ${ }^{2}$ John of Rupescissa was born around 1310 in the village of Marcolès, a few kilometers south of Aurillac. From about 1327 until 1332 he studied at the University of Toulouse, where-

1 Coote, Prophecy and Public Affairs in Later Medieval England, 13.

2 The first important study on John of Rupescissa appeared in the middle of the last century by Bignami-Odier, Études sur Jean de Roquetaillade (Johannes de Rupescissa), based on her École Nationale des Chartes thesis of 1925. A lightly revised version of the book was published under the title “Jean de Roquetaillade (de Rupescissa): Théologien, polémiste, alchimiste.” Lerner’s “Historical Introduction” to Rupescissa's Liber secretorum eventuum edition (Iohannes de Rupescissa, Liber secretorum eventuum, édition critique, traduction et introduction historique, ed. Lerner and Morerod-Fattebert, 13-85) offers a comprehensive study on his life, works and prophetical discourse; see also his more recent paper Lerner, "Life, Works, and Fortune of the Prophet Immured," $25-39$.

Note: I would like to thank Diarmuid Ó Riain for his help with the English translation and Cinzia Grifoni for her help with the Latin translation.

2 Open Access. (C) 2020 Elena Tealdi, published by De Gruyter. (c) BY-NC-ND This work is licensed under the Creative Commons Attribution-NonCommercial-NoDerivatives 4.0 License.

https://doi.org/10.1515/9783110597745-017 
upon he became a Franciscan friar, before continuing his studies until 1337. At that moment or very soon after, he was assigned a place at the Franciscan friary in Aurillac. ${ }^{3}$ It was during this first period of his religious life that the friar received and recounted some visions connected to the Antichrist's birth and life,${ }^{4}$ with the result that he came to be regarded as a visionary. Indeed, such a reputation was met with deep suspicion by the ecclesiastical authorities in Rupescissa's days, especially in Languedoc, where the heretical experience of the Beguins, a community of laypeople who lived according to the spiritual Franciscan model of strict poverty, ${ }^{5}$ had just been extirpated. The ecclesiastical authorities continued to perceive a threat in the aftermath of this movement, and it was in this atmosphere that John of Rupescissa's visions were met with great scepticism.

Despite the likely absence of any evidence of doctrinal heresy at the time, it is easy to understand why John would have been incarcerated in December 1344 by his own order, considering that his prophecy was probably aimed at criticising its leadership, and accused them - in accordance with Peter of John Olivi's preaching and writings - of laxity, moral abuses, and opulence. ${ }^{6}$

All of Rupescissa's works, which comprise about twenty prophetic texts - commentaries on prophecies and new prophetic texts, including two examples of alchemical writings - were produced within a short period, namely between the years $1348 / 49$ and 1357. From the Liber secretorum eventuum (1349) and the commentary on the Oraculum Cirilli (a medieval papal prophecy), we learn that, at the time of his imprisonment, he had been committed to writing an exposition on the "arcane revelations of Daniel" on the basis of a supernatural insight into the prophetic meaning of the Book of Daniel that he had received in Aurillac in $1340 .{ }^{7}$ He certainly continued to write during the years of Franciscan imprisonment, as we can read in the

3 See Lerner, "Historical Introduction," 15-16.

4 About these visions, see Lerner, "Historical Introduction," 24-27; Lerner, "Life, Works and Fortune of the Prophet Immured," 29.

5 On Provençal groups of Beguins and their connections to Olivi's memory and theology, see Burnham, So Great a Light, So Great a Smoke (in particular, on Olivi's eschatology and its influence on the Beguins, 17-20 and 36-40).

6 The circumstances surrounding the arrest and imprisonment of the "Franciscan prophet" are analyzed by Lerner ("Historical Introduction," 28-29; "Life, Works and Fortune of the Prophet Immured," 30-32), who excludes two theological and doctrinal reasons for his incarceration - the formulation of a literal millennialism and adhesion to the technical doctrine of Franciscan poverty - since Rupescissa formulated the first one after 1345 and was never completely favourable to the second. Nevertheless, the clear influence on Rupescissa of another work, Arnold of Villanova's De cymbalis ecclesie, probably offered the inquisitor Guillaume Farinier adequate grounds for ordering his arrest. On Arnold of Villanova, see: Potestà, "L'anno dell'Anticristo. Il calcolo di Arnaldo di Villanova nella letteratura teologica e profetica del XIV secolo," 431-463.

7 Iohannes de Rupescissa, Liber secretorum eventuum, ed. Lerner and Morerod-Fattebert, $\$ 18$ [p. 146]; the passage from the commentary on the Oracle of Cyril is quoted by Bignami-Odier, Etudes, 186. 
prologue of the Vade mecum in tribulatione, composed in 1356, where he speaks about the works composed during his time in the prison of Rieux. ${ }^{8}$

Remarkably, the friar's works were all produced in prison, owing to the fact that he was incarcerated almost without interruption from 1344 until his death around 1366. While the conditions of his first imprisonment - at the Franciscan convent of Figeac, some fifty kilometers south of Aurillac - were surely very hard, ${ }^{9}$ his final detention in Avignon, after a peregrination through several Franciscan prisons, offered him the extraordinary possibility of being in touch with the most important people of the ecclesiastical world..$^{10}$ It was in Avignon that he read and commented on almost all known Latin medieval prophetic texts and constructed his

8 “[...] and from the dungeon of Rieux with a letter written with my own hand I have made <that>" (Vade mecum in tribulatione, Prologue, ed. Tealdi, 222; English translation: Kaup, 149). His sprawling commentary on the Oraculum Cirilli seems to have been composed mostly between 1347 and the first half of 1349; for the dating of this text and the challenges it poses, see Lerner, "Life, Works and Fortune of the Prophet Immured," 35, who specifies that “Avignon was the point of departure for the circulation of all of Rupescissa's surviving works, including the commentary on Cyril, which he most likely brought with him and completed there."). After the Liber secretorum eventuum, completed in November 1349, Rupescissa wrote the letter Reverendissime pater (1350), De quinta essentia (an alchemical work: 1351-1352), the Sexdequiloquium (1352-1353), the Breviloquium de oneribus orbis (1354), the Liber lucis (another alchemical work: probably 1354), the Liber ostensor (1356), the letter Vos misistis (1356), the Vade mecum in tribulatione (1356) and the letter Flori rosarum (between 1356 and 1360). The modern editions of Rupescissa's works are the following: Boilloux, Etude d'un commentaire prophétique du XIV siècle: Jean de Roquetaillade et l'Oracle de Cyrille; Casteen, "John of Rupescissa's letter Reverendissime pater (1350) in the aftermath of the Black Death,” 139-179; Jean de Roquetaillade, Liber ostensor quod adesse festinant tempora, édition critique sous la direction d'A. Vauchez, par C. Thévenaz Modestin et Ch. Morerod-Fattebert; avec la collaboration de M.H. Jullien de Pommerol; sur la base d'une transcription de J. Bignami Odier; and the already cited editions of Liber secretorum eventuum (1994) and Vade mecum in tribulatione (2015). The early modern edition of his principal alchemical work remains standard: Iohannes de Rupescissa. Liber de consideratione quinte essentie omnium rerum. On his alchemical production, see: DeVun, Prophecy, Alchemy and the End of Time. On the extraordinary overall production of the friar minor, see Lerner, "John the Astonishing."

9 See Lerner, "Historical Introduction," 29.

10 The terrible nature of his first confinement is described by Rupescissa himself in book IX of the Liber ostensor (chapters 16-22 and 36: edition 517-521 and 528). See also Lerner, "Life, Works, and Fortune of the Prophet Immured,” 30. His final quarters were situated within the papal prison called "of the Sultan" (located somewhere apart from the papal palace) and were described by the Franciscan as an equally frightful place (Liber ostensor, 9.23, ed. Vauchez, 522). Nevertheless, an ever more frequent and wide use of prophetical and theological sources is evident in the works he wrote from the late forties onwards. The Sexdequiloquium and Liber ostensor clearly depended on the close reading of many other texts and extensive cross-referencing, which leads us to imagine him sat at a desk and to conclude that his living conditions in the papal prison cannot have been that bad. He was never actually condemned for heresy, and there is even reference to him being "relaxatus" by Clement VI in October 1350 (Vatican Archives, Collectoriae 50, f. 91v). This term is puzzling, but we can assume that it denoted a reduction in the severity of the conditions of his internment, as hypothesised by Potestà, “Gli spiriti dei profeti sono soggeti ai profeti,” 47-59, at 48, note 4. 
own prophetic system, which was deeply permeated by a belief in the imminent opening of a millennial reign of peace. This reign was considered in a literal sense and would open between 1365 and 1368, according to Rupecissa's eschatological computations, which were based on the books of the Bible, especially on that of the prophet Daniel. ${ }^{11}$ The political element never disappeared from Rupescissa's prophecies completely, but it began to play a different role. With the End Times approaching, he understood politics as a useful key to clarifying the present, revealing the near future, and explaining the deeper meaning of the past.

\section{The Emperor as the Apocalyptical Antichrist}

Rupescissa's eschatological plan first appeared in the Liber secretorum eventuum, written in 1349. It envisaged three successive periods: one between the present and 1366 that would see the rise of the Antichrist; the second between 1366 and 1370, consisting of the Antichrist's open reign; the third as a millennium of peace, which would extend between the Great Antichrist's destruction in 1370 and the final advent of Gog. The Liber secretorum eventuum was primarily concerned with identifying the Antichrist with a political figure of his own time, and he looked for him specifically amongst the descendants of Emperor Frederick II. ${ }^{12}$ The Provençal Beguins had seen Frederick III as Antichrist thirty years before, and now Rupescissa put the focus on Frederick II's grandson, Louis of Sicily, making clear that the

11 This "prophetic system" is recognisable within all of Rupescissa's prophetic works and was defined by Lerner as "the most detailed, internally coherent and influential Christian prophetic system of the fourteenth century" (Lerner, "Historical Introduction," 14). For a general introduction to medieval eschatology, see: Lerner, "Millennialism," 326-360. The works of Reeves and Töpfer remain very important: Reeves, The Influence of Prophecy in the Later Middle Ages; Töpfer, Das kommende Reich des Friedens.

12 In fact, the character of the Antichrist in Rupescissa's works is never alone, since the friar followed the Olivian expectation of two Antichrists, calling them "misticus" and "maximus", respectively. Applying this structure to the Hohenstaufen dynasty in his commentary on the Oraculum Cirilli, Rupescissa identified Louis the Bavarian with the mystic Antichrist and Louis of Sicily with the great one. In the Liber secretorum eventuum the structure is the same, since the two sovereigns are connected to different heads of the apocalyptical red dragon of Revelation 12 and named by the same epithet: "Louis of Bavaria with his antipope was the mystical, figurative and very solemn Antichrist, as already said. And, since it is said in the Revelation that "as for the beast that was and is not, it is an eight, but it belongs to the seven", this is the forthcoming Louis, that is quite a tyrant of the whole world. In fact, the emperor Frederick was the sixth king, while Louis the Bavarian is the seventh, and, so, Louis of Sicily will be the eighth" (Liber secretorum eventuum $§ 7$, ed. Lerner and Morerod-Fattebert, 140). 
prophetical and apocalyptic discourse in question introduced not only a political landscape but also, more exactly, a dynastic scheme of succession. ${ }^{13}$

While Rupescissa had not ruled out associating the Antichrist with a pseudopope ${ }^{14}$ in the Oraculum Cirilli prophecy, ${ }^{15}$ in the Liber secretorum he proceeded to identify some churchmen as benign apocalyptic characters, and announced the coming of five angelic popes who were destined to destroy the enemies of Christianity, lead heretics back to the Church, and institute reform. They would serve between the then incumbent pope, Clement VI, and the open reign of the Antichrist. ${ }^{16}$

13 The fourth paragraph of the Liber secretorum eventuum is entitled "Intellectus primus in revelatione patrum et generis Antichristi et nominis eius et persone et loci" and identifies the Apocalyptic enemy of the Church with the king of Sicily: "At first, I understood that the forthcoming Antichrist will be born from the lineage of Emperor Frederick and King Peter of Aragon; and I understood that the young king of Trinacria, who keeps the island of Sicily, Louis himself is the forthcoming universal king of the whole world, under whom the Holy Roman Church will cry" (Liber secretorum eventuum §4, ed. Lerner and Morerod-Fattebert, 138); in the fifth paragraph, Rupescissa explains that he has to be identified with the apocalyptical beast of Revelation 13, since the sea he will arise from is the Mediterranean Sea around Sicily itself and his partial defeat was realised when "the heretic Frederick was deposed from his imperial power and, during the reign of Manfred, all their venomous lineage was destroyed on the field of Benevento, by the blessed and celebrated French race" (Liber secretorum eventuum §5, ed. Lerner and Morerod-Fattebert, 139).

14 This is the subject of $\S \S 19-26$ of the Liber secretorum eventuum (see, in particular, $\S 21$, ed. Lerner and Morerod-Fattebert: "It will occur, with the permission of God, that, with the suggestion of a counterfeiter and in offence to Christ and the pope, another one, son of ambition and pride, will be elected as pseudo-pope, sustained by a group of many cardinals denying the real pope;" The figure of the pseudo-pope would be transcribed in the subsequent Sexdequiloquium but did not appear in the last works of the friar. About the evolution of the image of the pseudo-pope, see Potestà, "Il profeta degli Anticristi, del reparator e del millennio," 51 and n. 40.

15 The core of the prophecy was the contrast between Celestine V and Boniface VIII, modelled on the biblical conflict between Roboam and Jeroboam (cfr. I Kings 12). On the content of the prophecy, see Potestà, L'ultimo messia, 166.

16 The role of these popes is described in §§ 56-59 of the Liber secretorum eventuum, which have the following incipit: "Therefore, the greatest pope, who will immediately succeed the aforementioned lord pope that currently reigns, will be a most pious man, elected by a single nod from God and anointed by the Holy Spirit and strengthened from heaven by the Archangel Michael's special protection and consoled by his personal visitations. Thus, God will pour the Holy Spirit and prudent zeal onto him to repair what is collapsed and to rebuild what is destroyed. He will plan to do astonishing, admirable and most divine things and will attempt to accomplish useful things, on account of which he will suffer grievously. But finally, by command of God, he will escape the perils and achieve victory over his false enemies." (Liber secretorum eventuum § 56, ed. Lerner and MorerodFattebert, 165). Paragraph 20 had already introduced the figure of a saintly pope, connected to Celestine's memory: "Thus, according to the command of the almighty God, it will happen that the confined cardinals cannot agree on anybody except upon a certain man, who is most pious and anointed by God. He will not be chosen from the order of the cardinals, but rather in the same way as they once selected the most pious Celestine; indeed, this man will be elected with due observance and canonically." (Liber secretorum eventuum § 20, ed. Lerner and Morerod-Fattebert, 147). 
Although it seemed that this opposition between the great enemy of the Church and its saintly defender would long remain a fixed part of the friar's eschatological vision, this did not prove to be the case. While the role of Louis of Sicily declined in subsequent works, ${ }^{17}$ the apocalyptical enemy began to be explicitly called the Antichrist and was now not always to be identified with a specific sovereign. This is true of the De oneribus orbis, a commentary on the prophecy Veh mundo in centum annis, written in 1354, in which the last adversary of the Church is, according to the Book of Revelation, identified with Lucifer, the Beast arising from the sea or the false prophet, but no longer has a personal name. ${ }^{18}$

On the other hand, the concept of the saintly pope also underwent complex development in the year following the writing of the Liber secretorum eventuum. This is clear from the difference between the popes as described in the 1349 work, in which their portrayal was closely connected to the papal prophecy Genus nequam ${ }^{19}$ - which also culminated in four saintly figures - and the popes that featured in subsequent works, where a progressive abandonment of this prophetic source is evident.

In fact, some years later, while he was writing another long theological and prophetical work, entitled Sexdequiloquium, Rupescissa no longer quoted from this set of prophecies. Nevertheless the close correspondence between the units 11-16 of Genus nequam and the Sexdequiloquium's description of the final events until the coming of the Beast ${ }^{20}$ make clear that he adopted the same theological structure and framework of apocalyptic expectation. He also comments on the saintly pope's evangelical life, implicitly identifying him as a Franciscan, and further notes that this pope will be "crowned by angels". ${ }^{21}$ It is in this work that Rupescissa invented the term reparator, used as a personal name (and no longer an adjective, as in the preceding commentary to the Oraculum Cirilli) that served to identify a pope as having a specific eschatological role that was no longer based on the first papal series,

17 The same "prudential" attitude towards the personal identification of the Antichrist and the immediate applicability of the final fights to specific dynasties can be found in the Franciscan pseudo-Joachimite Summula seu Breviloquium super concordia Novi et Veteris Testamenti, written between 1350 and 1355 in Catalonia and containing an exposition of Joachim of Fiore and Peter of John Olivi's prophecies. For the edition of the text, see: Summula seu Breviloquium super Concordia Novi et Veteris Testamenti, ed. Lee, Reeves and Silano. Fundamental is also the paper by Robert E. Lerner, "Origine, contenuto e fortuna della Summula pseudo-gioachimita;" see also Potestà, "Il profeta degli Anticristi," 50-51 and note 37.

18 Potestà, "Il profeta degli Anticristi," 51.

19 Dependent on a Byzantine model of imperial prophecies called Oracula Leonis, the papal series was preceded by a cardinal series prophecy showing a strong anti-Orsinian perspective (i.e. a polemic against the Orsini, the powerful Roman family to which many cardinals and three twelfthand thirteenth-century popes belonged), and ran into the beginning of the fourteenth century, where the same ecclesiastical polemic again comes to the fore. See Potestà, L'ultimo messia, 160162. For the edition of the text, see Fleming, The Late Medieval Pope Prophecies.

20 Mesler, "John of Rupescissa's Engagement."

21 Sexdequiloquium V 4,2,12, as quoted in Mesler, “John of Rupescissa’s Engagement.” 
but instead connected to the thirteenth motto (Iste solus clare aperiet librum scriptum digito Dei vivi) of another prophecy, Ascende calve..$^{22}$ The latter was aimed at denigrating the papacy and contradicted the theological meaning of the Genus nequam in that it introduced a structure culminating with a diabolic figure. Nonetheless, Rupescissa did not hesitate to utilise the Ascende calve - which he had only recently discovered - in his Sexdequiloquium, ${ }^{23}$ using the thirteenth motto, which implicitly referred to Pope Celestine, to help shape the ideological construction of his reparator. ${ }^{24}$

In the meantime, Rupescissa's apocalyptic character of the poor, saintly pope grew more and more independent of the existing tradition of papal prophecies and ended up being identified not with a prophetical figure but with two biblical ones, the angel of Revelation 10:1 (the angelus habens libellum apertum) ${ }^{25}$ and the mystical Elijah of Matthew 17:11. He was now characterised by Christological traits, especially by the typological use "in a second sense" of those prophetical passages of the Old Testament traditionally connected to the advent of Christ.

It might appear, therefore, that the journey from the Liber secretorum eventuum (and the commentary on the Oraculum Cirilli before it) to the works of the next decade brought with it the progressive elimination of the imperial horizon from $\mathrm{Ru}$ pescissa's eschatological structure. But this was not (or, at least, not yet) entirely the case.

\footnotetext{
22 Both the dating of the Ascende calve and the milieu in which it was redacted are still subjects of controversy, but we can situate it in an Italian Spiritual Franciscan context between 1328 and 1330, according to Schwartz and Lerner, "Illuminated Propaganda." Regarding the debate around the redaction of the prophecy, see Potestà, L'ultimo messia, 178 and related note 104.

23 Mesler explains the change in the Sexdequiloquium concerning the integration of the new prophecy into the overall system in this way: "However, his reference to this prophecy is subtle. Rupescissa describes the coming pope as one 'who will kill Nero [and] heal the wounded', where Nero represents Pope Innocent VI." This image, as Lerner pointed out to me, draws on Ascende calve 13: "Rise and be valiant. Kill Nero and you will be secure; heal the wounded." Unlike the previous prophecies, Rupescissa does not mention this one by name, nor does he give any indication that he is referring to a prophetic text (Mesler, "John of Rupescissa's Engagement”).

24 There is also evidence that Rupescissa wrote a - now lost - commentary on the prophecy, in particular on the thirteenth image: "On him I have written many treatises in abundant speech in several of my books, that is in my Commentary on the Prophetic Book Horoscopus and in the two Commentaries on the Book of the Tablets of God to Cyrill and in my Commentary on the prophetic book about the supreme pontiffs, which begins: Arise, Baldhead, and in the Commentary on the canon which begins: To the Heights you are called, oh Prince [...]." (Vade mecum in tribulatione, int. 9, ed. Tealdi 237; English translation: Kaup 191).
}

25 As argued in Tealdi: Hic est angelus in manu habens libellum apertum. 


\section{The French Emperor as a New Good Actor}

In fact, another benign character emerged to accompany the reparator within the apocalyptic scenario, as we can see in the Liber ostensor quod adesse festinant tempora and the Vade mecum in tribulatione, both written only a few months apart in 1356. The Liber ostensor, slightly older and much longer than the second work, was structured along clearly pro-Angevin and anti-Aragonese lines. ${ }^{26}$ It culminated in the anticipation of an emperor of the End Times whose French origins are strongly emphasised and reinforced by allusion to different prophecies, thus making the book a sort of prophetical encyclopaedia and showing the great extent of Rupescissa's library.

Very different in structure and dimension from the Liber ostensor, the Vade mecum in tribulatione is a short work directed towards obtaining salvation, and was widely disseminated. ${ }^{27}$ Those willing to put their trust in Rupescissa's prophetic predictions about the imminent coming of the two Antichrists were urged to convert to a poor, evangelical life on the model of Christ and the Apostles. In structure, the work has twenty short chapters or intentions (intentiones). The prologue takes the form of a letter to magister Petrus Perrier, a Franciscan and a scholar of medicine. The first intention looks at the conversion of infideles, the destruction of heretics and schismatics, and the unity of the Latin and Greek Churches. The second, third, and fourth intentions are concerned with the conversion of secular clergy to the model of Christ's life, the persecution of clergy who remained in sin, and the final escape of the Roman Curia from Avignon. The fifth discusses the calamities expected to befall the world between the years 1360 and 1365, including the arrival of both the Eastern and Western Antichrists. ${ }^{28}$ The sixth intention relates to the then recent defeat of the French army at the Battle of Poitiers on 19 September 1356,

26 The following quotations illustrate this point: "The second opinion is that this black rooster will be a worldly emperor who will have to be elected from among the people of the Gauls after the death - as I believe - or around the time of 'the beast ascending from the sea' (Apoc. 13:1). The reparator will choose him to reign without any election by the Alamanns [Germans]. He will be a rooster, which means from the family of the royal Gallic Franks, and black, because of the great penance. And he will reign over all, in the West and in the East, and will order the execution of the reparator's orders. And his chickens, the many Gallic noblemen, will be destined to care for the whole world from this moment on." (Liber ostensor, 5.45, ed. Vauchez, 300-301); "In the same treatise it is expressly said that an angelic poor man, evangelical reparator of the future world, will take someone on from the Pippin's lineage against the German use of the election. And this man will repair the world together with him, and will make the Christian faith rule everywhere." (Liber ostensor, 4.46, ed. Vauchez, 163-164).

27 Its shortness was probably the main reason for its extraordinary diffusion. Within a few decades it had spread across Europe, from Spain to Bohemia, from Sweden to Italy, not only in the original Latin language but also in French, German, English, Italian, Castilian, Catalan, and Czech.

28 The theme of the double Antichrist (see above, note 7) obtains a peculiar geographical characterisation in the Vade mecum, since the two Antichrists are expected to come from different regions of the world and act together. 
which is interpreted as an sign within the context of Rupescissa's sequence of events leading to the apocalypse indicating the beginning of the persecution and ultimate restoration of the Church. The seventh intention deals with the clergy's loss of material goods, and the eighth describes the Western Antichrist. The ninth to twelfth describe the actions of benign apocalyptic characters, namely the reparator and the two witnesses of Revelation 11:3, identified as friars minor, as well as a saintly French king. The thirteenth and fourteenth intentions discuss the persecution of both regular clergy and the Order of Friars Minor, while the fifteenth predicts the persecution of important towns. The sixteenth intention can be considered to be the core of the work: it explains the meaning of being saved in the aftermath of the Antichrists' persecution. The seventeenth, eighteenth, and nineteenth intentions depict the appearance of the Western Antichrist and the events immediately before, during, and after the millennium of peace. The twentieth and final intention is a compendium of the prophetic quotations used by the author in building the chronology of the eschatological plan.

Both in the Liber ostensor and the Vade mecum in tribulatione, the second apocalyptic character was represented as a temporal sovereign whose role was to follow and support the reparator. ${ }^{29}$ In writing these two works, Rupescissa used the Liber de Flore, a prophecy written in a Spiritual Franciscan milieu during Pope Boniface's reign, ${ }^{30}$ to shape the image of the emperor of the End times. Because there is no reference to this prophecy in the Sexdequiloquium, ${ }^{31}$ we can assume that it was unknown to our author until the first years of the 1350s.

As a new acquisition for his prophetical library, the Liber de Flore offered $\mathrm{Ru}$ pescissa the precious new perspective of a perfect cooperation between temporal and spiritual powers, who were qualified to become actors in the messianic destiny of the Church. The unification of the Roman and Greek Churches, the end of the Byzantine Empire, and the dominion over Jerusalem exercised by the Angevin sovereign after the reconquest of Sicily were to be the most significant actions of this benign emperor, whose death in Constantinople would be followed by a range of miracles. ${ }^{32}$

29 As stated in the twelfth intention of the Vade mecum in tribulatione: "Against the custom of the German election he will raise up the king of the French, who will come at the beginning of $<$ the restorer's > election to see his evangelical brilliance, as Roman emperor. To him God will subjugate the whole world in general: the West, the East and the South. He will arise in such a great holiness that no emperor or king since the beginning of the world ever will have equaled him in holiness except the King of Kings and Lord Jesus Christ.” (Vade mecum, int. 12, ed. Tealdi, 243; English translation: Kaup, 209, 211).

30 On this work, see: Potestà, L'ultimo messia, 170-172. The first study of this prophecy was undertaken by Grundmann, "Liber de Flore."

31 As pointed out by Mesler, "John of Rupescissa's Engagement."

32 These miraculous signs after death are referred to explicitly in the Vade mecum, where, however, they relate to both the pope and the emperor: "The whole world will be restored by these two, and by them will be destroyed all the law and tyrannical power of Mohammed. Both, the pope and the 
After the French emperor's death, the saintly pope (the second in a series previously announced in the text), who would also be a Frenchman, would wield both temporal and spiritual power, and within a year restore peace between Germany and France, where the ruling dynasty would not be re-established. A significant passage relating to the acquisition of temporal power by the pope sees the latter refusing to be crowned out of reverence for Christ's crown of thorns. This element of the crown plays a fundamental role in both the Liber ostensor and Vade mecum, but there is a notable difference in how it is presented.

In the Liber ostensor Rupescissa includes numerous lengthy quotations from the Liber de Flore that were to be read together with some quotations from the $\mathrm{Vi}$ siones of the monk Sergius. ${ }^{33}$ The passage concerning the refusal of the crown in the Liber de Flore is quoted in full, with the pope consistently referred to as the spiritual pastor and identified as the successor of the dead first reparator. ${ }^{34}$ The passage is quoted again in a later chapter, after a temporal sovereign has been identified as a "king from the Occident" in line with Sergius' Visiones. ${ }^{35}$ It is clear from the text,

emperor, will personally visit Greece and Asia, extinguish the schism, liberate the Greeks from the Turks, subjugate the Tartars to the faith, restore the kingdoms of Asia. And the pope will decree that forever, as long as the world exists, <some> cardinals will be taken from the Greek Church. He will ascend the mountain that is called Taurus in Asia to take back Asia. In Italy he will end the schism of the Guelphs and Ghibellines and put the lands of the Church into such an order that the Church will never fight again because of them. He will extirpate greed and arrogance from the clergy. He will annihilate the heresies. And since, as I have said, it will soon happen that the unbelievers will invade Italy, Hungary and many Christian countries and afflict Christendom literally for months, it is he who will destroy them and liberate the Christian people from Mohammed's hands. [...] After nine years and a half or nine months or thereabouts, he will finish his life and the emperor after ten years and a half or thereabouts. And in death both will shine through great miracles." (Vade mecum, int. 12, ed. Tealdi, 243-244; English translation: Kaup, 211, 213, 215). We thus read here that the pope would have died after nine and a half years, as did the emperor in the Liber de Flore, while the king's reign would have lasted ten and a half years. This second figure depends on another prophecy entitled Visiones, which was composed in the ninth or tenth century by the monk Sergius. This figure is a legendary character of the Christian and Islamic tradition. The Visiones, known to Rupescissa from a thirteenth-century Latin version, referred exactly to the expectancy of an occidental saintly king. See Bignami-Odier, Levi Della Vida, "Une version latine de l'Apocalypse syroarabe de Serge-Bahira."

33 See note 33 and Liber ostensor, ed. Vauchez, 920-922, on the use of the Visiones in Rupescissa's prophetical work.

34 "During the reign of the successor of the first pauper reparator, the temporal rector will die, and in the town of Constantinople will dissolve a debt with God, and he will shine, after his death, because of a huge number of miracles. Another poor man will assume his temporal power. The already named successor will be present at the temporal rector's death and will preach in a very kind way that somebody from his lineage be placed on his own honorable throne. And this one, when he conquers the temporal dominion, will immediately refuse to be crowned with the golden crown, because of his reverence for the Crucifix." (Liber ostensor, 6.64, ed. Vauchez, 352: cfr. Liber de Flore, ms. Arras, Bibliothèque municipale, 138, fol. 99).

35 "A king will come from the West and will reign in the whole world for one and half weeks. This is the precious king described by Joachim, who has to be chosen from the French lineage by the poor 
though not expressly stated, that the pope will refuse the crown, while the emperor will not. Moreover, a few lines before the above-mentioned passage, the reader is provided with further information on the mission of the king, who is said to have been called to reunify the whole world under the dominion of God. ${ }^{36}$ This emphasis on political action, and its essential role, suggests that, unlike the pope, the king will not be expected to renounce his crown, once he has been called upon to exercise his full dominion over the world in order to ensure Christ's universal reign.

The scenario presented in the Vade mecum in tribulatione diverges considerably from the Liber de Flore's model. First of all, in Rupescissa's version the conversion of infideles all around the world would not be achieved by a human character (neither emperor nor pope), but by God himself or, perhaps, come about through a series of favourable coincidences. ${ }^{37}$ Secondly, the key twelfth intention states clearly and unambiguously that the apocalyptic actor expected to renounce his crown is the king. ${ }^{38}$ This means that the saintly king is ordered and expected to exercise his redemptive role precisely by renouncing the symbol of his temporal authority. There is a difference between the two works, therefore, in how the balance between the two powers, the temporal and the spiritual, is presented. While the Liber ostensor, in accordance with its Liber de Flore template, describes the two powers as being perfectly equal (albeit within a relationship of loyalty and obedience), the Vade mecum in tribulatione offers the idea of a precise hierarchy between them. ${ }^{39}$ At the

friar minor emperor. And he will refuse to be crowned with the golden crown." (Liber ostensor, 6.77, ed. Vauchez, 362).

36 "He will conquer the infidels' towns and subjugate them. And he will hit them with his sword, because he is the one who will be ordered by the emperor to free the whole world from all the mistaken sects and to realize one herd with one pastor under Jesus Christ's dominion." (Liber ostensor, 6.78, ed. Vauchez, 362).

37 "God's first intention, however, is to gather - during the tribulations that have begun and are to increase from stage to stage - the whole world in the one Catholic faith [...] to convert the Jews, Saracens, Turks, Tartars, and to lead the Greeks back to the unity of the general Church, and to extirpate completely from the earth all the schismatics, the heretics in their entirety [...] For rather should heaven perish and the earth be reduced to nothingness, than that the word of Christ in the 10th chapter of John should fail, who says: Other sheep I have, which are not of this flock; them also I must bring, and there shall be one flock, and one shepherd." (Vade mecum, int. 1, ed. Tealdi, 223224; English translation: Kaup, 153, 155). Note the use of the same quotation from the Gospel of John 10.16 here as in the passage from the Liber ostensor cited in the preceding note.

38 "This emperor will be recognised in this, that, for the sake of honoring Christ's crown of thorns, he will refuse to be crowned with a golden crown" (Vade mecum, int. 12, ed. Tealdi, 243; English translation: Kaup, 211).

39 The Liber ostensor, quoting the Liber de Flore (ms. Arras, Bibliothèque municipale, 138, fol. 98), at book 6, chapter 63, affirms that "the spiritual pastor and the temporal rector will have a common will and a common perfection; what will be ordered by one of them, will be executed by the other" (ed. Vauchez, 352); on the other hand, the Vade mecum in tribulatione emphasises the complete dependence of the temporal sovereign on the spiritual reparator: "This holiest emperor will be the executor of all the mandates of the mentioned restorer (reparator)" (Vade mecum, int. 12, ed. Tealdi, 243; English translation: Kaup, 211). 
core of the dynamic balance aspect we find the symbol of the crown and the connection between it and Christ's crown of thorns. Its significance is not surprising if we consider the devotion to the holy crown "invented" and practised by Louis IX, king of France from 1226 to 1270. It is tempting to see in Rupescissa's attitude a re-establishment of apocalyptic expectations concerning the French crown, reinforced by the use of the prophetic authority of the Liber de Flore, but at the same time updated by the implicit reference to the more recent reign of Louis IX. The situation is not so simple, however.

In 1238/9, the French sovereign Louis IX obtained the crown of thorns from the emperor of Constantinople. Its acquisition and the building of the Parisian SainteChapelle to house it are the highpoints in the shaping of the theological and political meaning associated with the circulation of these most important Christian relics during the Middle Ages. ${ }^{40}$ For the French king, the possession of Christ's crown was an irrefutable signal of both his superiority in comparison to other monarchies and his divine investiture within the whole Christian community. The crown was, therefore, a visual sign and proof of the connection between spiritual guidance and temporal dominion. Charismatic leadership had always been a particular element of dynastic legitimisation, but during the reign of Louis IX it assumed the dimension of moral - and not simply political - hegemony, which was evoked through reference to divine and supernatural investiture. The problematic nature of this conception is evident, on one hand, in the refusal of the papacy to universalise veneration of the holy crown and, on the other, perhaps, in the effort made by Louis's brother, Charles I of Anjou, to obtain Louis' canonisation, which arguably represented an actual admission of papal moral supremacy. Indeed, the symbolic construction and liturgical propaganda bound up with the crown of thorns decreased after the king's death, while the Roman Curia re-elaborated the figure of the saintly king with the aim of using it for the purposes of celebrating the superiority of ecclesiastical authority.

Although it seems somewhat paradoxical, Louis' canonisation obfuscated the celebration of the crown insofar as it turned the king into the foremost purveyor of the universal obedience owed to the Church, thereby diminishing the cult's original theological and political message. Rupescissa's works were written some decades after Pope Boniface VIII's canonisation of the saintly king of France in 1297, and their evolution must be viewed in the context of the difficult and rarely productive relationship between the two wielders of universal powers - the Church and the monarchy - in the intervening period. It is immediately evident that a simple shift of balance, applying the phrase renuet coronari to the emperor rather than the pope, could cause a considerable change of perspective: the saintly and humble sovereign of Rupescissa's prophecies is no longer the pope, as in the original

40 The short explanation of this topic here is dependent on the important volume of Chiara Mercuri, Corona di Cristo, corona di re, 105-211. 
prophecy, and instead reverts to the apocalyptic figure of the emperor. Nevertheless, the latter character is an imperator sanctissimus, who reigns with the reparator while being wholly obedient to him.

It is pertinent at this point to examine the manuscript tradition of the Vade mecum in tribulatione, as it may assist in the interpretation of the text's development. The tradition of the Latin text is very complex, with copies transcribed all across Europe, particularly in the century and a half after Rupescissa's writing (from 1359, only three years after the original redaction, to the middle of the sixteenth century).

It is not possible to establish a stemma codicum that relates all manuscript families to a unique original, nor can this archetypal text be identified with any certainty in the surviving copies. Nevertheless, a French manuscript family of the text, named $\alpha$ in the recent edition, shows some peculiar characteristics that allow it to be identified it as clearly a very important version. ${ }^{41}$

It is of some significance that all the manuscripts of this family are French; one of them is the oldest known exemplar of the Latin tradition, ${ }^{42}$ while another, even if datable only to the fifteenth century, contains a very coherent text that displays a deep understanding of the prophetical meaning of the Vade mecum. ${ }^{43}$ So, too, does the earliest French translation, which is also the oldest witness of the text (1358) and was likewise written in France. ${ }^{44}$ None of these manuscripts include the phrase ob honorem sancte corone spinarum Christi, ${ }^{45}$ thereby reducing the refusal of the crown to a simple act of humility, without any reference to the political and theolog-

41 See the ratio editionis in Rupescissa, Vade mecum in tribulatione, ed. Tealdi, 136-157.

42 Brügge, Stadtbibliothek 416: described in Rupescissa, Vade mecum in tribulatione, ed. Tealdi, 96-97; it is dated to 1359 (the same date is given for the ms. Venezia, Biblioteca Marciana Lat. III 39, but only for the folios containing the Vade mecum).

43 Vaticano, BAV Reg. Lat. 1964: described in Rupescissa, Vade mecum in tribulatione, ed. Tealdi, 115-116.

44 This translation is attested in a manuscript of the second half of the fourteenth century: Paris, Bibliothèque nationale del France, Fr. 24254. Concerning this manuscript and the French translation, see Ferrari, "La prima traduzione francese del Vade mecum in tribulatione di Giovanni di Rupescissa (Paris, BnF Fr. 24254)." Some remarks on the relationship between the Latin and French versions are expressed in Rupescissa, Vade mecum in tribulatione, ed. Tealdi, 136-157 (ratio editionis of the family) and is more extensively examined in Ferrari, "La più antica traduzione francese del Vade mecum in tribulatione (ms. Paris, BnF, fr. 24254).”

45 "For the sake of honoring Christ's crown of thorns" (see also n. 38). The same omission can be found in a French translation as well: "Il prenra et fera empereur de Rome, contre la coustume de l'eleccion d'Alemaigne, un roy de France qui sera au commencement de sa creacion pour enduire et manifester au monde la clarté euvangelique d'icellui Reparateur du monde; au quel empereur Dieu sousmettra generalment tout le monde: Orient, Occident et Midi; et sera de si grant sainteté que onques ne fu roy ne empereur pareil a sa sainteté et sa prodommeye, fors seulement nostre Seigneur Jhesu Crist le souverain Roy des Roys. Cestui empereur sera congneu a ce que il refusera estre couronné de couronne d'or": Ferrari, "La più antica traduzione francese del Vade mecum in tribulatione (ms. Paris, BnF, fr. 24254),” 57. 
ical implications of the possession of the holy relics. It seems impossible to establish whether this variant reflects authorial intention or not, but we can at least assume that the entire older French tradition did not contain any reference to King Louis' actual expectations. ${ }^{46}$ The omission of any direct reference to Christ (and his crown) would seem to signal the increased role of the Church, which was expected to become the foremost arbiter within Christianity during the End Times. Nevertheless, the apocalyptic character of the saintly emperor also endured in undiluted form, at least within the Latin manuscript tradition, in which all other witnesses containing the entire text contain the complete sentence. ${ }^{47}$ Furthermore, the abbreviated

46 This observation is supported by a similar omission from the comparably early Catalan version of the Vade mecum, as pointed out by Marco Pedretti: "Aquest farà emperador aquell rey de França qui vindrà en lo començament quant ell serà papa - e açò serà contra la costuma de la elecció qui·s solie fer en Alamanya - al qual Déus sotsmetrà tot lo món; lo qual emperador serà de tan gran santedat, que negun emprerador ni rey no li serà stat semblant del començament del món tro ara; aquest emperador sobresant serà execudor de tots los manaments del dit papa Reperador": Pedretti, "La traduzione catalana del Vade mecum in tribulatione (ms. Carpentras, Inguimbertine, 336)," 166-167.

47 It is particularly significant that an important group of manuscripts circulated quite early in England, constituting a group easily identifiable as a family (family y of the ratio editionis: see Giovanni di Rupescissa, Vade mecum in tribulatione, ed. Tealdi, 171-188). Among these, two manuscripts (London, British Library, Royal 8 E VIII and Oxford, Bodleian Library, Eng. Th. 57) have what are evidently marginal notes (sometimes interpolated into the text, so probably copied from an older exemplar). The note concerning the twelfth intention presents an interesting example of the phenomenon of the eschatological horizon being updated, when it suggests that the emperor would be called "Taurus" (this is an "intentional" mistake from the original reference to the Taurus as a region of Asia), since he would reign in both England and France, and could thus be identified with the English king, Henry VI of Lancaster: "This reparator will drive all the corrupted, simoniacal, mean and lustful priests away from the temple of God. At the beginning of the emperor's reign, he will choose a French king, who will be very saintly. Note that the emperor and the king will destroy the law of Muhammad and will visit Greece and Asia. Note that the emperor will go to Asia and that he will be called 'bull' and that somewhere the king of England is called a bull with two horns that is the English and the French crown: only God exactly knows his identity, but I think he is the present king of England." See Rupescissa, Vade mecum in tribulatione, ed. Tealdi, 312-314. Manuscripts containing excerpts of the text could also correctly render the characterisation of the emperor. For example, the Italian ms. London, Wellcome Institute Library 507, on fol. 1 presents a singular abbreviated version that focuses on the spiritual element of the religious conversion, but not without frequent reference to the apocalyptic characters of the eleventh and twelfth intentions. In particular, it reads: "The pope will nominate as Christian emperor the French king reigning at the time. And he will have so great a holiness, virtue and goodness that no king will ever have had the like, Christ excepted. In fact, he refused to be crowned with the golden crown, since he thought that the king of the universe had been crowned with a crown of thorns in an act of terrible cruelty." (See Rupescissa, Vade mecum in tribulatione, ed. Tealdi, 305-307). Nevertheless, the ascription of a predominantly spiritual or political-revolutionary sense to the text by later redactors often brought with it the elimination of any reference to imperial power; examples of these two tendencies at work can be found in Wrocław, Biblioteka Universytecka I Q 72m (writing only: "Then the pope will destroy all the heretics and other infidels with their heresies." See Rupescissa, Vade mecum in tribulatione, ed. Tealdi, 309-311) and the more important Wien, Österreichische Nation- 
version $^{48}$ does not omit the entire content of the twelfth intention, and is actually one of the less contracted forms of the Vade mecum. This points to the existence of both a strong tradition of the text and a deep comprehension of the contents of the passage.

\section{No More King?}

Although the Vade mecum is much shorter than the Liber ostensor and it takes and develops the main themes of the earlier treatise, it cannot simply be considered to be a summary. The two works can be seen as mutually independent pieces, with the political discourse itself as the principal grounds for comparison between them. Indeed, it is the modified political scenario and background of these works that can be used to explain the discontinuity between them. In the Vade mecum, the emperor's role is significantly reduced to that of a mere agent of the reparator, described only in the second part of the twelfth intention before disappearing. ${ }^{49}$ The reduction of his role cannot be explained simply by the constriction of the apocalyptic landscape to a few pages, given that a considerable difference in the roles allocated to the spiritual and temporal characters can be observed in the work.

A specific change of perspective had come about in Rupescissa's eschatological plan, as can be established by focussing on the biblical quotations in the two works (Liber ostensor and Vade mecum) and identifying some possible lines of interpretation. A particular quotation from Isaiah 28:19 that is found in both the Liber ostensor and the Vade mecum (and here more frequently) is very significant in this regard. The quotation (sola vexatio intellectum dabit auditui) seems to be the "driving force" of this eschatological dynamism, because it reveals as an indispensable precondition for the opening of the millennium of peace the deep connection between tribulatio and conversio, then conversio and predicatio, and finally predicatio and the

albibliothek 3282, that, according to Robert E. Lerner's definition of "popular justice”, omits any reference to both temporal and spiritual power, leaving it to the lay people the role to destroy the corrupted clergy (see Rupescissa, Vade mecum in tribulatione, ed. Tealdi, 301-305) and, for the context of the redaction of the text, Lerner, "Popular Justice."

48 The abbreviated version of the Vade mecum in tribulatione survives in diverse forms, including a group of manuscripts containing a text with all the intentions in abbreviated form and lacking the prologue; a shorter version circulated in England. These manuscripts contain only some abbreviated intentions, but, significantly, always include the twelfth one. See Rupescissa, Vade mecum in tribulatione, ed. Tealdi, 200-208.

49 The second part of the intention includes complete list of their actions, where it is made clear that the emperor neither does anything by himself nor works without the spiritual pope (see the quotation above, n. 33). 
conversio of the infideles. ${ }^{50}$ As for the character refusing the royal crown in the two texts, here the focus shifts from the temporal to the spiritual. The Vade mecum features a temporal sovereign who has renounced his political role and its symbol (the crown). He is a truly "disempowered" king, who, because of his consequent inability to change the condition of the world, is no longer the object of eschatological admonition. Thus the addressee of Isaiah's admonition is identified as the Church and the French monarchy in the Liber ostensor, ${ }^{51}$ while it is to be equated with the Church alone in the Vade mecum in tribulation..$^{52}$ What happened in the few months between the writing of the Liber ostensor and of the Vade mecum, respectively? Why was the French king no longer an addressee of the Old Testament prophet in the Vade mecum? On 19 September 1356, the French army was destroyed at the Battle of Poitiers and King John II imprisoned at Bordeaux (together with a large number of French nobles). He was destined to remain there until 11 April of the following year, when he was transferred to London, where he stayed until 8 May $1360 . .^{53}$ These events affected a key element of Rupescissa's eschatological scenario: the French monarchy could no longer be considered a good interlocutor and actor in his eschatological scenario. The friar therefore not only eliminated the allocution to the monarchy, but also continued with the construction of a new hermeneutical plan

50 It is worth mentioning that Isaiah's quotation is used surprisingly rarely in the Franciscan and Spiritual literary works of the thirteenth and fourteenth centuries, even in works that explicitly involve the connection between persecution and salvation, such as Angelo Clareno's Historia septem tribulationum; in fact, we find a very similar use of that quotation only in Arnald of Villanova's Tractatus de tempore adventus Antichristi, which was surely a source of Rupescissa's eschatological plan: "And so the terrifying voice is necessary to do these things [...], as it is written in Isaiah's prophecy: And it will be sheer terror to understand the message. Actually, the tribulations of punishment and persecution and the terror of dying and forthcoming judgement could upset the men whose hearts have not totally parted with the expectation of eternal life" (ed. Perarnau i Espelt, "El text primitiu del De mysterio cymbalorum Ecclesiae d'Arnau de Vilanova," 138. On Arnald's eschatological timetable and its influence, see also Potestà, "L'anno dell'Anticristo."

51 "I was saying [...]: 'God's will be done! Maybe affliction will give them the intellect to come back to their fathers and predecessor kings' way of living and ruling.' And I understood that, since they had abandoned the humility and the holiness of the old way of ruling, because of that a lot of troubles had occurred to them" (Liber ostensor, 4.51, ed. Vauchez, 168).

52 In the second and shorter text the central theological theme is the persecution of the clergy, which ends with the extreme possibility of conversion before the beginning of the millennium of peace, and ultimately with the divine election of a saintly pope. This is evident from intentions 3 : "Those, however, who according to the words of Isaiah scourged shall receive understanding, will be preserved by God with the holy prelates and clerics as seeds." (Vade mecum, ed. Tealdi, 227; English translation: Kaup, 163), 7: "[...] the affliction shall give them understanding, and they will humbly recognize their guilt” (Vade mecum, ed. Tealdi, 234; English translation: Kaup, 183), and 9 ("For when through these tribulations [...] this affliction shall confer understanding, Christ, through the ministry of the holy angel, will cause one supreme pontiff to be elected [...]" (Vade mecum, ed. Tealdi, 235; English translation: Kaup, 187).

53 The echo of the defeat of Poitiers was significant, not only in Rupescissa's eschatology but also in the external and internal politics of France. See, among others, Green, The Battle of Poitiers, 1356. 
that took into account the new status quo; the defeat of Poitiers was not omitted, but rather became a part of the "eschatological mechanism". The defeat of the French monarchy was necessary in order that the Church be left alone and unprotected, so that its persecution became inevitable; the persecution of the Church was in turn necessary in order to lead it to the conversion that would bring about the gathering of saintly men who would be able to pray for the infidels' conversion and the world's eschatological salvation.

The political landscape remained a fundamental element of the eschatological plan, but it was recast as a pre-existing and unavoidable starting point within a dynamic of cause-and-effect; it was part of the fixed past, no longer of a malleable present that, even up until the composition of the Liber ostensor, it was possible to question and to direct. ${ }^{54}$ The final months of the year 1356 pushed some other developments into Rupescissa's eschatological thinking. A short text beginning with the words Verba fratris Iohannis can be found in a prophetical section of a fourteenthcentury English manuscript and also in an erudite collection of prophecies compiled in Mantova in the last quarter of the fifteenth century. ${ }^{55}$ Although this text is called a summary of the Liber ostensor in the first manuscript ${ }^{56}$ and of the Vade mecum in tribulatione (or actually the Liber ostensor itself) in the second one, ${ }^{57}$ it has to be considered a new and independent text. ${ }^{58}$ This short and extremely precise text has

54 This dynamic of cause-and-effect has a specific rhetorical expression in the Vade mecum. The negation of possibility (non possibilis est) and the hypothetical sentence in the past tense: something would have happened before that (citius quam) something else could happen. The three fundamental steps of the eschatological plan (the French monarchy's defeat, persecution of the Church, conversion of infidels) are also presented in the Vade mecum in a non-chronological sequence (first intention: conversion of infidels; second one: Church persecution; sixth one: defeat of French monarchy), with a consequent emphasis on the necessary connection between the three events. The internal structure of the text is explained at 76-77 of the critical edition.

55 For the description of the two manuscripts (Cambridge, Corpus Christi College, 138; Paris, Bibliothèque nationale de France, Lat. 16021), see Rupescissa, Vade mecum in tribulatione, ed. Tealdi, 128 and 130-131; see also Liber ostensor, ed. Vauchez, 857-859.

56 Ms. Cambridge, Corpus Christi College, 138, fol. 184r: Verba fratris Johannis de Rupecissa ordinis minorum de futuris eventibus stupendis et de certis annorum cotationibus eorumdem, abreviata de libro qui intitulatur Ostensor futurorum.

57 Paris, BnF, Lat. 16021, fol. 5v: Verba fratris Iohannis Repetissa qui dicitur Vade mecum in tribulatione, ordinis fratrum minoris, de futuris evenientibus stupendiis et ceteris annorum abreviate de libro eius intitulato Ostensor quot adesse festinant tempora ad dominum cardinalem Petragoricensem. The grammatical structure of the sentence is not very clear, since it would suggest that the friar and not his work is called Vade mecum in tribulatione.

58 I thank Robert E. Lerner, who suggested this interpretation to me during a discussion on the Vade mecum in tribulatione edition, that took place in Milan on 3 December 2015. He argued that the author of the Verba fratris Iohannis was Rupescissa himself, because of some peculiar linguistic structures and images, as well as a number of intentional and carefully chosen omissions (in particular, the millenarian references) that could hardly have been done by someone else. Lastly, in the Paris manuscript the author speaks of the French king as dominum meum regem Franchorum and it is easy to hear the voice of the Franciscan prophet in this. Since this work was written a few months 
several elements in common with the Vade mecum and correctly organises the concatenation of events from the defeat of the French army to the persecution of the Church and the intervention of eschatological characters to rescue Christianity. In it, the French emperor seems to play the same role as in the Vade mecum (although with a significant difference between the two manuscripts) and is explicitly said to renounce his crown because of his reverence for Christ. ${ }^{59}$ It should be noted that in the Parisian manuscript the imperial character actually disappears entirely, while the pope plays his eschatological role according to an updated fifteenth-century "schedule". ${ }^{60}$ Even if the change of dates suggests a later re-writing of the text, it is notable that the additional chapter is in fact a new exposition of the first intention of the Vade mecum; secondly, the sentence et similis ei papa non fuit et a morte sancti Petri circa is an exact repetition of the original celebration of the emperor in the Vade mecum. ${ }^{61}$ These two details could suggest that the scribe knew and was reading the Vade mecum directly, and - possibly - that the Verba fratris Iohannis had originally circulated in two versions, one with the two eschatological figures and one with the saintly pope alone. Or perhaps Rupescissa himself hesitated between the two solutions - and this would be a fascinating hypothesis - while he was "reconceiving" his Vade mecum.

A few months after the Vade mecum was redacted, another text flowed from the pen of Rupescissa. The friar wrote a letter addressed to Étienne Aldebrand, archbishop of Toulouse, beginning with the words "Vos misistis". Some themes of the

after the Vade mecum, before the end of the year, it is clearly a "reconsideration" of the Vade mecum and has as its most prominent element - but not the only one - the re-establishment of the correct order of events from the year 1357 to the 1365. See Lerner, "Yet Another Work by John of Rupescissa."

59 In its final part the short eschatological treatise, which can be characterised as a synopsis of intentions 6, 5, 4, 7, 8, 9, 11, 12 (in this order) of the Vade mecum, reads: "In the year 1360 or a bit later, there will be this good shepherd's entrance. This forthcoming celestial reparator, coming from the saintly French kings' lineage and from their own home, will elect a king for the glory of the Roman empire; and Christ will submit to him all the world from East to West; and nobody will be able to take position against him. This very saintly man will be humble and will refuse to be crowned with the golden crown because of the reverence towards Christ's crown of thorns. The emperor will live about ten and half years; and the reparator nine years and nine months" (Cambridge, Corpus Christi College, 138, fol. 84v).

60 "And it will be not so long from the year of our Lord 1470, before or after the entrance of that man who will suffer persecution at the hands of his own friends during the years 1475, 1476 and 1477. So, there will be one flock and one shepherd all around the world. And starting from Saint Peter's death there has been no pope like him. He will save the world and restore it to its original sanctity and unity" (Paris, BnF, Lat. 16021, fol. 6r). Et ab anno Domini 1470 non distabit multum, ante vel post introductionis ejus, quem persecutionem patietur a suis intra annum Domini 1475, 1476, 1477. Fiet unum oville et unus pastor in mundo. Et similis ei papa non fuit et a morte sancti Petri circa. Qui et enim universum mundum recuperabit et ad ipsum reducet, ad sanctitatem et unitatem antiquam.

61 "He will arise in such a great holiness that no emperor or king since the beginning of the world ever will have equaled him in holiness except the King of Kings and Lord Jesus Christ." (Vade mecum, int. 12, ed. Tealdi, 243; English translation: Kaup, 209, 211; see above, note 30). 
Vade mecum were once again broached therein: the escape of the Curia from Avignon, the persecution of the clergy, the general decline in human solidarity, and the increase in European wars and aggression by external enemies. ${ }^{62}$

Besides the shared elements some changes can also be noted in the eschatological scenario presented. A reparator is expected, but he would be neither a pope nor a friar minor, but simply an angelus vicarius Christi. Above all, he would not be supported by anybody, neither by the two eschatological characters nor a temporal emperor. At the end of the letter, Rupescissa uses the image of the "wheel of fortune" (rota fortunae), whose turning periodically brings about success or defeat in human events. Fortune, like Christian Providence, is understood as an instrument of divine omnipotence. It will destroy proud men and radically change the destiny of the world. A conversion is expected for humanity, but the role of any saintly man (both the reparator and the emperor) is entirely reduced: ${ }^{63}$

But after countless tribulations, and after the controversies at hand inside the Christian community are over, God's benevolence will come to the foresaken people, since one angel, Christ's representative - who has knowledge of all of his intentions and who will lead every churchman back to the way of life of Christ and the Apostles - will extinguish almost all sin and will sow all evangelical virtues in the world. He will convert the Jews, destroy many of the Saracens, convert the Tartars, but destroy the Turks, who refuse to convert to Christ. The whole world will be pacified under him and peace will last about one thousand years. And then, from this time on, evil will grow in the world, the mighty ruler will mourn, the king will wear the sadness, the power of the people will have been destroyed, until the future representative of

62 The letter often circulated together with the Vade mecum in tribulatione and may be read in eight of the manuscripts: Basel, Universitätsbibliothek, A V 39; Bremen, Staats- und Universitätsbibliothek, b 35; Göttingen, Stadt-Archiv, 7; Milano, Biblioteca Trivulziana, 199; Oxford, Bodleian Library Rawlinson D 339; Wroclaw, Biblioteka Uniwersytecka, I Q 112; London, British Library, Cotton Vespasian E VII; London, British Library, Royal 7 A IX (this last manuscript presents a short text depending on the letter Vos misistis and the fifth intention of the Vade mecum, signifying that its author had probably read them together in another manuscript). See also Bignami-Odier, Études, 174-175.

63 This section of the unedited letter is here transcribed from the ms. Basel, Universitätsbibliothek, A V 39, fol. 124r, where Vos misistis is followed by the letter Reverendissime pater and then the Vade mecum: Sed post tribulationes innumerandas et transactis scandalis in Christianitate propinquis, misericordia Dei veniet ad desolatam gentem, quia unus angelus vicarius Christi, qui sciet omnes voluntates eius, qui universos ecclesiasticos reducet ad modum vivendi Christi et apostolorum, universa fere scelera extirpabit, omnes virtutes evangelicas seminabit in mundo. Iudeos convertet, plurimos destruet Sarracenos, Tartaros convertet, Turcos autem destruet, nolentes converti ad Christum; totus orbis sub ipso pacificabitur et pax fere mille annis durabit. Et ideo, ab hoc tempore et ultra, mala crescent in mundo, princeps magnus lugebit, rex induetur merore, manus populi dissolvetur, donec mittatur ille Christi vicarius futurus et totius destructi seculi reformator: felix qui orabit pro illo ut cito veniat; sed tamen interim orator penitentiam agat. Salvabuntur omnes qui fugient de medio malorum ad montes, quia vindicta Domini generaliter et specialiter [erit] super omnes, felices et infelices. Felices igitur omnes prenominati in cedula si in pace bene morientur: moriantur et cito, ne videant tot mala, et ad quos eorum hereditates devolvantur non curent, quia qui acquirit non possidebit et qui possidet quod possidet non retinebit, quia rota fortune iam venit ad casum antedictum. 
Christ and the reformer ${ }^{64}$ of the whole devastated world will be sent: blessed is the man who will pray for him to come soon; however, he should do penance in the meantime. All those who will flee from evil to the mountains will be saved, since the Lord's vengeance will come over each and everyone, the blessed and the unblessed. And blessed will be all who were mentioned in the text before, if they die well and in peace: and let them die soon, so that they do not have to see so much evil, and do not have to worry about whom they would leave their inheritance to, since he who acquires will not own anything, and he who owns will not keep what he possesses, because the wheel of fortune has already come to bring the afore-mentioned fall.

We may imagine that this was the end of the parabola of Rupescissa's political prophetic discourse. The defeat of the temporal power, the Capetian king, brought the dissolution of the expectations Rupescissa had placed in him; consequently, the prophet's attention turned to supernatural actors, who operated completely independently of human affairs.

\section{Conclusion}

The development of Rupescissa's prophetical works shows a continuous process of change and updating, and the figure of the emperor offers a very interesting focus for analyzing this process. The emperor is present in Rupescissa's earliest works from the 1340s, where - based on the political propheticism connected with Peter of John Olivi - he is cast in a very negative role. In the subsequent works, following on from Louis IV the Bavarian having abandoned the political scene, the negative character begins to be identified simply as the Antichrist (without any additional name given). Meanwhile, a new character appears on the scene: he is the figure of a king of France of the end times, the reparator, whose role is bound up with notions of salvation and spiritual power, and continues to be developed in the later works. After the devastating defeat of King John II near Poitiers, the emperor's function undergoes a great change, with reflection on the eschatological meaning of the crown, connected to the image of Christ's crown of thorns, playing an important role in the transformation. Finally, in his last short works from the same year, 1356, Rupescissa seems to hesitate with regard to the very permanence of the imperial character; the epilogue of the Vos misistis letter ultimately sees the temporal power disappear and the spiritual one substituted by the impersonal figure of fortune, while the human saintly pope turns into an angelus vicarius Christi, an angel representing Christ.

64 Other manuscripts have "reparator" instead of "reformator". 


\section{Bibliography}

\section{Primary Sources}

John of Rupecissa. Liber de consideratione quinte essentie omnium rerum. Basel, 1561.

John of Rupecissa. Liber ostensor quod adesse festinant tempora. Édition critique sous la direction d'A. Vauchez, par C. Thévenaz Modestin et Ch. Morerod-Fattebert; avec la collaboration de M.H. Jullien de Pommerol; sur la base d'une transcription de J. Bignami Odier. Edited by André Vauchez. Rome: École française de Rome, 2005.

John of Rupecissa. Liber secretorum eventuum, édition critique, traduction et introduction historique. Edited by Robert E. Lerner and Christine Morerod-Fattebert. Fribourg: Éditions Universitaires Fribourg Suisse, 1994.

John of Rupecissa. Vade mecum in tribulatione. Edizione critica a cura di Elena Tealdi. Introduzione storica a cura di Robert E. Lerner e Gian Luca Potestà. Edited by Elena Tealdi. Milan: Vita e Pensiero, 2015.

John of Rupescissa. Vade mecum in tribulatione. Translated into Medieval Vernaculars. Edited by Robert E. Lerner and Pavlína Rychterová, Milan: Vita e Pensiero, 2019.

Summula seu Breviloquium super Concordia Novi et Veteris Testamenti. Edited by Harold Lee, Majorie Reeves, Giulio Silano. In Western Mediterranean Prophecy. The School of Joachim of Fiore and the Fourteenth-Century 'Breviloquium'. Vol. 88, Studies and Texts. Toronto: Brepols, 1989.

\section{Secondary Literature (and Online Resources)}

Bignami-Odier, Jeanne and Giorgio Levi Della Vida. "Une version latine de l'Apocalypse syro-arabe de Serge-Bahira." Mélanges d'Archéologie et d'Histoire 62 (1950): 125-148.

Bignami-Odier, Jeanne. Études sur Jean de Roquetaillade (Johannes de Rupescissa). Paris: Vrin, 1952.

Bignami-Odier, Jeanne. “Jean de Roquetaillade (de Rupescissa): Théologien, polémiste, alchimiste.” Histoire littéraire de la France 41 (1981): 75-240.

Boilloux, Marc. "Étude d'un commentaire prophétique du XIVe siècle: Jean de Roquetaillade et l'Oracle de Cyrille," Thesis de l'École nationale des Chartes, Paris 1993.

Burnham, Louisa A. So Great a Light, So Great a Smoke. The Beguin Heretics of Languedoc. Ithaca: Cornell University Press, 2009.

Casteen, Elizabeth. “John of Rupescissa's Letter Reverendissime pater (1350) in the Aftermath of the Black Death." Franciscana 6 (2004): 139-179.

Coote, Lesley Ann. Prophecy and Public Affairs in Later Medieval England. York: York Medieval Press, 2000.

DeVun, Lea. Prophecy, Alchemy and the End of Time. John of Rupescissa in the Late Middle Ages. New York: Columbia University Press, 2009.

Ferrari, Barbara. "La prima traduzione francese del Vade mecum in tribulatione di Giovanni di Rupescissa (Paris, BnF Fr. 24254).” Studi Mediolatini e Volgari 50 (2004): 59-76.

Ferrari, Barbara. "La più antica traduzione francese del Vade mecum in tribulatione (ms. Paris, BnF, fr. 24254)." In John of Rupescissa. Vade mecum in tribulatione. Translated into Medieval Vernaculars. Edited by Robert E. Lerner and Pavlína Rychterová, 25-71. Milan: Vita e Pensiero, 2019. 
Fleming, Martha H. The Late Medieval Pope Prophecies. The 'Genus nequam' Group. Tempe: Arizona Center of Medieval and Renaissance Studies, 1999.

Green, David. The Battle of Poitiers, 1356. Stroud: The History Press, 2008.

Grundmann, Herbert. "Liber de Flore. Eine Schrift der Franziskaner - Spiritualen aus dem Anfang des 14. Jahrhunderts." In Ausgewählte Aufsätze, 2: Joachim von Fiore, edited by Herbert Grundmann, 101-162. Vol. 25, MGH Schriften. Stuttgart: Hiersemann, 1977.

Lerner, Robert E. “'Popular Justice'. Rupescissa in Hussite Bohemia.” In Eschatologie und Hussitismus, edited by Alexander Patschovsky and František Šmahel, 39-52. Praha: Historisches Institut, 1996.

Lerner, Robert E. "Historical Introduction." In Iohannes de Rupescissa. Liber secretorum eventuum, édition critique, traduction et introduction historique, edited by Robert E. Lerner and Christine Morerod-Fattebert, 13-85. Fribourg: Éditions Universitaires, 1994.

Lerner, Robert E. "John the Astonishing." Oliviana: Mouvements et dissidences spirituels (2009): https://oliviana.revues.org/335. [accessed 1 July 2019]

Lerner, Robert E. "Life, Works, and Fortune of the Prophet Immured." In Giovanni di Rupescissa. Vade mecum in tribulatione, edizione critica a cura di Elena Tealdi, introduzione storica a cura di Robert E. Lerner e Gian Luca Potestà, edited by Elena Tealdi, 25-39. Milan: Vita e Pensiero, 2015.

Lerner, Robert E. "Millennialism." In The Encyclopedia of Apocalypticism, vol. 2, edited by Bernard McGinn. New York: Continuum, 1998.

Lerner, Robert E. "Origine, contenuto e fortuna della Summula pseudo-gioachimita." In Profezie illustrate gioachimite alla corte degli Estensi, and edited by Gian Luca Potestà, 11-36. Modena: Franco Cosimo Panini, 2010.

Lerner, Robert E. "Yet Another Work by John of Rupescissa." Oliviana: Mouvements et dissidences spirituels (2016): on-line: http://oliviana.revues.org/825. [accessed 1 July 2019]

Mercuri, Chiara. Corona di Cristo, corona di re. La monarchia francese e la corona di spine nel medioevo. Rome: Edizioni di storia e letteratura, 2004.

Mesler, Katelyn. “John of Rupescissa's Engagement with Prophetic Texts in the Sexdequiloquium.” Oliviana. Mouvements et dissidences spirituels XIIle-XIVe siècles (2009): http://oliviana.revues.org/331.

Pedretti, Marco. "La traduzione catalana del Vade mecum in tribulatione (ms. Carpentras, Inguimbertine, 336)." In John of Rupescissa. Vade mecum in tribulatione. Translated into Medieval Vernaculars. Edited by Robert E. Lerner and Pavlína Rychterová, 143-176. Milan: Vita e Pensiero, 2019.

Perarnau i Espelt, Josep. "El text primitiu del De mysterio cymbalorum Ecclesiae d'Arnau de Vilanova. En apèndix, el seu Tractatus de tempore adventus Antichristi." Arxiu de Textos Catalans Antics 7-8 (1988/89): 7-169.

Perarnau i Espelt, Josep. "La traducció catalana medieval del Liber Secretorum Eventuum de Joan de Rocatalhada." Arxiu de Textos Catalans Antics 17 (1998): 7-219.

Potestà, Gian Luca. "Gli spiriti dei profeti sono soggeti ai profeti. Da Giovanni di Rupescissa a Pietro Galatino." In "Per una severa maestra." Dono a Daniela Romagnoli, edited by V. Scotti Douglas, 47-59. Fidenza: Mattioli 1885, 2014.

Potestà, Gian Luca. "L'anno dell'Anticristo. Il calcolo di Arnaldo di Villanova nella letteratura teologica e profetica del XIV secolo." Rivista di Storia del Cristianesimo 2 (2007): 431-463.

Potestà, Gian Luca. L'ultimo messia. Profezia e sovranità nel Medioevo. Bologna: il Mulino, 2014.

Reeves, Marjorie. The Influence of Prophecy in the Later Middle Ages: A Study in Joachimism. 0xford: At the Clarendon Press, 1969.

Schwartz Orit and Lerner Robert E. "Illuminated Propaganda: The Origins of the «Ascende Calve» Pope Prophecies." Journal of Medieval History 20 (1994): 157-191. 
Tealdi, Elena. "Hic est angelus in manu habens libellum apertum. The Use and Meaning of Apocalyptic Angels in Prophetical Works: The History of a Biblical Model from Joachim to Rupescissa." Annali di Scienze Religiose 5 (2012): 171-197.

Töpfer, Bernhard. Das kommende Reich des Friedens: Zur Entwicklung chiliastischer Zukunftshoffnungen im Hochmittelalter. Berlin: Akademie-Verlag, 1964. 